\title{
Schwannoma of ascending colon treated by laparoscopic right hemicolectomy
}

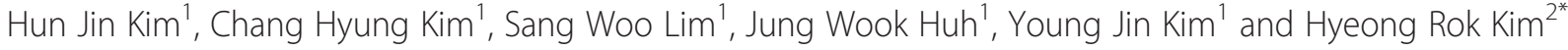

\begin{abstract}
Schwannomas of the colon are rare and are difficult to diagnose preoperatively, since they often defy endoscopic and radiographic detection. Immunohistochemical stains are useful postoperatively to confirm this tumor, but more reliable diagnostic techniques (such as colonoscopic biopsy with immunohistochemistry) have emerged to enhance preoperative diagnostic accuracy. Here we report an instance of schwannoma arising in the ascending colon, where immunohistochemical staining of a preoperative biopsy facilitated diagnosis. After laparoscopic resection, histologic examination was confirmatory.
\end{abstract}

Keywords: Schwannoma, Ascending colon, Immunohistochemistry

\section{Background}

Schwannomas of the gastrointestinal tract are relatively uncommon and rarely involve the large intestine [1-3]. Although considered benign, they may recur locally (if incompletely excised), and malignant transformation is occasionally observed $[4,5]$. Radical surgery is, therefore, the accepted standard of treatment.

While accurate diagnosis prior to surgical intervention can aid in therapeutic planning, limitations of conventional imaging and lack of sufficient biopsy material usually make this difficult. Recent improvements in colonoscopic techniques have led to use of endoscopic biopsy and immunohistochemistry in combination as a more reliable method for accurate preoperative assessment. We report here an instance of schwannoma of the ascending colon, confirmed by immunohistochemistry, for which laparoscopic right hemicolectomy was performed.

\section{Case report}

A 61-year-old male was referred to his local hospital for a routine health examination. On screening colonoscopy, a polypoid lesion of the ascending colon was discovered (Figure 1). A subsequent biopsy showed only signs of chronic ulceration (fibrinoid necrosis and neutrophils),

\footnotetext{
* Correspondence: regend0001@hanmail.net

${ }^{2}$ Department of Surgery, Chonnam National University Hwasun Hospital and Medical School, 160 Ilsimri, Hwasun-eup, Hwasun-gun, Jeonnam 519-809, Korea

Full list of author information is available at the end of the article
}

so he was transferred to our hospital for further evaluation and treatment.

The patient's physical examination was noncontributory, but we obtained multiple colonic biopsies. The mass was composed of benign spindle cells (Figure 2) strongly positive for $\mathrm{S}-100$ protein and negative for smooth muscle actin, CD117 and CD34 (Figure 3). This histochemical profile was compatible with schwannoma.

Abdominopelvic computed tomography (CT) indicated that the lesion of the ascending colon protruded intraluminally, exhibiting homogenous enhancement (Figure 4). A well- circumscribed, fungating mass $(1.7 \mathrm{~cm} \times 1.8 \mathrm{~cm})$ was ultimately resected via laparoscopic-enabled right hemicolectomy with side-to-side ileocolic anastomosis (Figure 5). Histologic evaluation, including immunohistochemistry, confirmed the tumor as schwannoma. Postoperatively, the patient recovered and has done well with no recurrence.

\section{Discussion}

Schwannomas are uncommon neoplasms arising from Schwann cells of the neural sheath $[2,6]$. They may occur anywhere in the body, but gastrointestinal sites are rare, especially the colon [1-3,7-12]. Depending on tumor size and location, schwannomas of the colon may occasionally produce symptoms, such as constipation, bleeding, abdominal pain or discomfort, and anal pain $[2,10]$. Intussuception is unusual [12]. Most patients, 


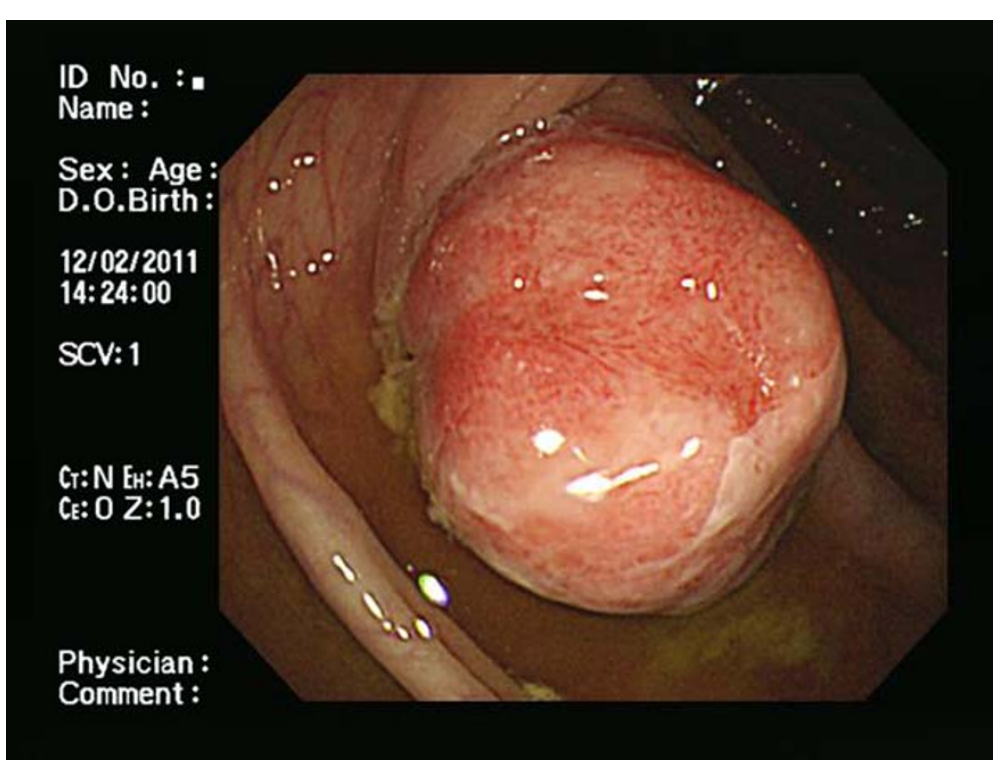

Figure 1 Semipedunculated polypoid lesion $(2 \mathrm{~cm})$ of the ascending colon by colonoscopy: note coating of whitish exudate.

slow-growing neoplasms $[9,13]$. In our patient, tumor discovery was incidental.

Preoperative diagnosis of schwannoma is difficult due to its tissue density and the tendency for ulceration [2]. Biopsies are often nondiagnostic, and information gained by other means is limited. Colonoscopy, abdominal ultrasound (US), abdominal CT and abdominal magnetic resonance imaging (MRI) may aid in evaluating the contours of colorectal schwannomas and their relationship with surrounding organs, as well as tumor multiplicity or metastasis. Levy, et al. [14] described gastrointestinal schwannomas as homogeneously attenuated and welldefined mural masses on CT, noting that they were indistinguishable from gastrointestinal stromal tumors. Low-attenuation hemorrhage, necrosis and internal

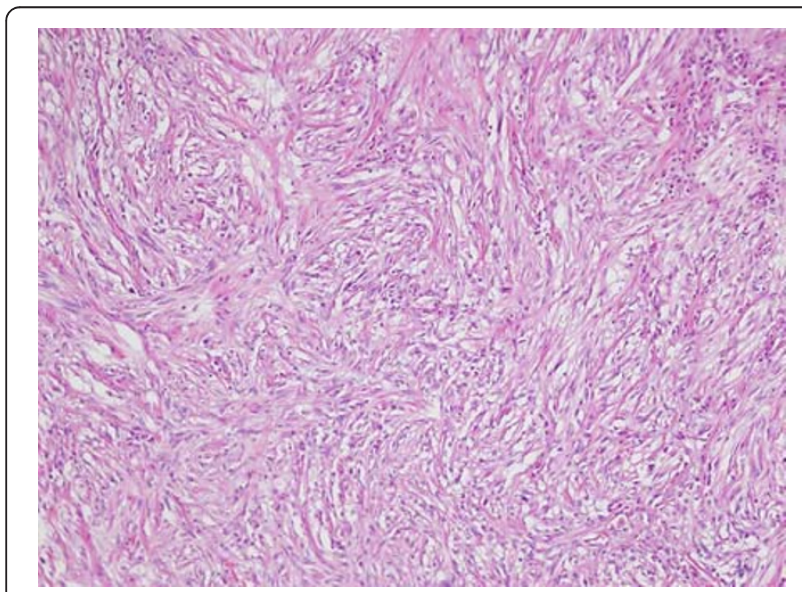

Figure 2 Microscopic view of mass showing spindle cell aggregate (10X, 100X). degeneration constituted shared CT features. Attributes signifying benign vs malignant behavior were not addressed [15,16]. More recently, endoscopic ultrasonography (EUS) surpassed other imaging modalities in diagnostic accuracy but still will not differentiate a schwannoma from other gastrointestinal stromal tumors. EUS-guided fine needle aspiration or biopsy of submucosal tumors has been attempted [17-20].

Schwannoma of the colon usually is not diagnosable solely by routine histology. A newer, more reliable approach incorporates immunohistochemistry $[2,7]$. Characteristically, these tumors are composed of spindle cells (much like neurofibromas, gastrointestinal stromal tumors and leiomyomas) $[7,21]$ that are $100 \%$ immunoreactive for S-100 protein. Cells of neurofibroma show

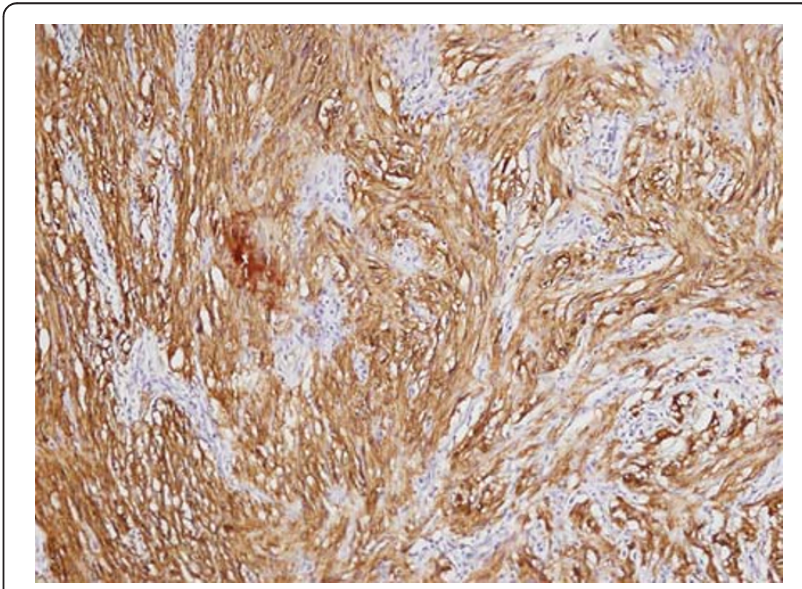

Figure 3 Strong immunoreactivity of tumor cells to S-100 protein. 


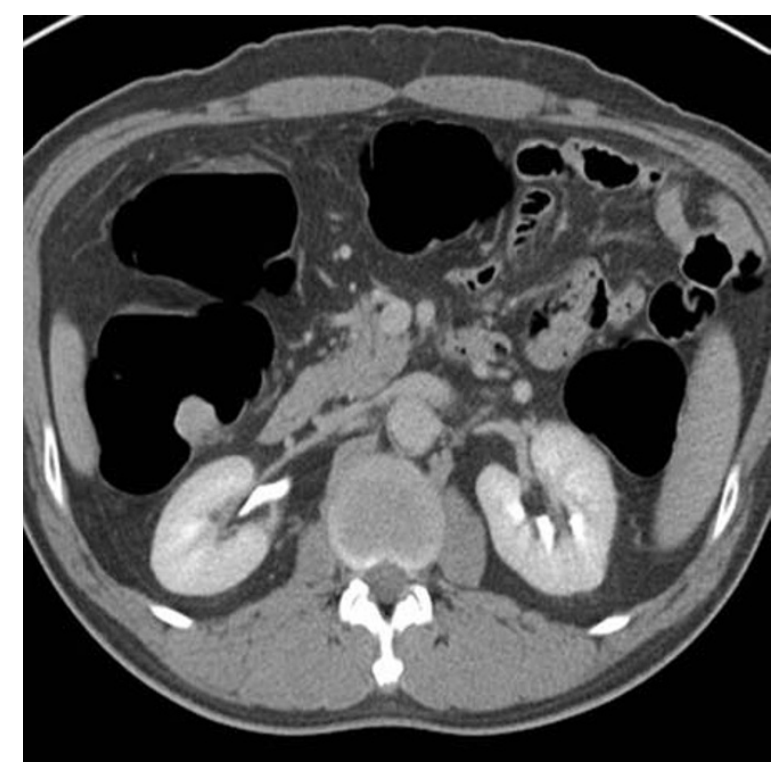

Figure 4 Homogeneous enhancement of mass on abdominopelvic CT.

less S-100 positivity (30\% to $40 \%$ ), while gastrointestinal stromal tumors are generally positive for CD117(c-kit) and CD34 (70\%) and negative for S-100 protein. Leiomyomas similarly are devoid of S-100 protein, expressing smooth muscle actin and desmin instead [22,23].

Because the prognosis for schwannoma differs from other gastrointestinal stromal tumors, a correct diagnosis is critical. Schwannomas overall are considered benign, but they may recur locally if excision is incomplete and in rare instances are capable of malignant transformation [4,5]. Tozbikian et al. [5] found that gastric schwannomas on occasion could be aggressive, progressing rapidly and responding poorly to chemotherapy.

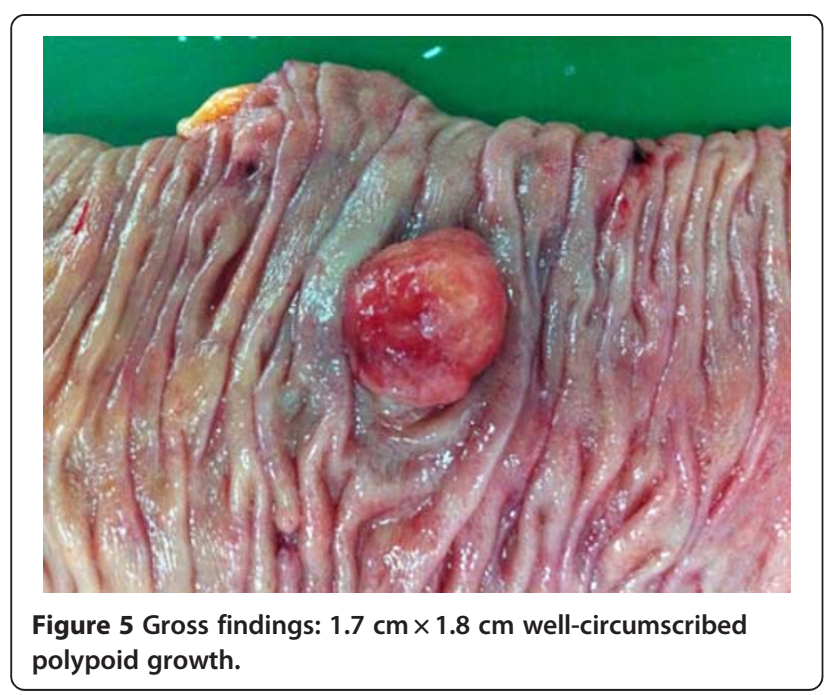

Standard treatment for schwannomas is complete surgical resection [4,24]. The role of radiotherapy or chemotherapy to date remains unclear $[4,25]$. Lymph node resection is not recommended, because the risk of malignant change is low [24,26]. A minimally invasive procedure (in our case, laparoscopic surgery) is acceptable for schwannoma of the colon and rectum $[8,13,27]$. Our patient resumed oral feeding on the second postoperative day and after an uneventful stay, was discharged on the sixth postoperative day. In clinical follow-up, he has been well and problem-free.

\section{Conclusion}

In conclusion, schwannomas of the ascending colon are rare tumors dependent upon immunohistochemistry for definitive classification. Accurate preoperative diagnosis is essential for appropriate surgical management. While radical resection affords optimal outcomes, a laparoscopic approach may be used.

\section{Consent}

Written informed consent was obtained from the patient for publication of this report and any accompanying images.

\section{Competing interests}

The authors declare that they have no competing interests.

\section{Authors' contributions}

HJK wrote the main manuscript and HRK performed the operation, revised, the manuscript for important intellectual content, and gave the final, approval for the version to be submitted for publication. All authors read and approve the final manuscript.

\section{Author details}

'Department of Surgery, Chonnam National University Hwasun Hospital and Medical School, Gwangju, Korea. ${ }^{2}$ Department of Surgery, Chonnam National University Hwasun Hospital and Medical School, 160 Ilsimri, Hwasun-eup, Hwasun-gun, Jeonnam 519-809, Korea.

Received: 27 January 2012 Accepted: 12 March 2012 Published: 15 May 2012

\section{References}

1. Abraham SC: Distinguishing gastrointestinal stromal tumors from their mimics: an update. Adv Anat Pathol 2007, 14:178-188.

2. Inagawa S, Hori M, Shimazaki J, Matsumoto S, Ishii H, Itabashi M, Adachi S, Kawamoto T, Fukao K: Solitary schwannoma of the colon: report of two cases. Surg Today 2001, 31:833-838.

3. Chetty R, Vajpeyi R, Penwick JL: Psammomatous melanotic schwannoma presenting as colonic polyps. Virchows Archiv 2007, 451:717-720.

4. Fotiadis Cl, Kouerinis IA, Papandreou I, Zografos GC, Agapitos G: Sigmoid schwannoma: a rare case. World J Gastroenterol 2005, 11:5079-5081.

5. Tozbikian G, Shen R, Suster S: Signet ring cell gastric schwannoma: report of a new distinctive morphological variant. Ann Diagn Pathol 2008, 12:146-152.

6. Matsuki A, Kosugi S, Kanda T, Komukai S, Ohashi M, Umezu H, Mashima Y, Suzuki T, Hatakeyama K: Schwannoma of the esophagus: a case exhibiting high 18 F-fluorodeoxyglucose uptake in positron emission tomography imaging. Dis Esophagus 2009, 22:E6-E10.

7. Hou YY, Tan YS, Xu JF, Wang XN, Lu SH, Ji Y, Wang J, Zhu XZ: Schwannoma of the gastrointestinal tract: a clinicopathological, immunohistochemical and ultrastructural study of 33 cases. Histopathology 2006, 48:536-545. 
8. Park KJ, Kim KH, Roh YH, Kim SH, Lee JH, Rha SH, Choi HJ: Isolated primary schwannoma arising on the colon: report of two cases and review of the literature. J Korean Surg Soc 2011, 80:367-372.

9. Mysorekar W, Rao SG, Jalihal U, Sridhar M: Schwannoma of the ascending colon. Indian J Pathol Microbiol 2010, 53:198-200.

10. Min YW, Kim YH, Yun HS, Kil JS, Kim YC, Yun SH, Kim KM, Kim JJ: A case of benign schwannoma in the ascending colon. Korean J Gastroenterol 2007, 50:398-401.

11. Ozawa T, Watanabe H, Okuyama Y, Okumura K, Tsuchiya T, Tanji N, Anzai Y, Unakami M: [A case of schwannoma of ascending colon.]. Nihon Shokakibyo Gakkai Zasshi 2001, 98:167-173.

12. Wani HU, Al Omair A, Al Shakweer W, Ahmed B: Schwannoma of the ascending colon with ileocolic intussusception. Trop Gastroenterol 2010, 31:337-339.

13. Suh SW, Park JM, Choi YS, Cha SJ, Chang IT, Kim BG: Laparoscopic approach to a case of appendicular schwannoma. J Korean Soc Coloproctol 2010, 26:302-306.

14. Levy AD, Quiles AM, Miettinen M, Sobin LH: Gastrointestinal schwannomas: CT features with clinicopathologic correlation. AJR Am J Roentgenol 2005, 184:797-802.

15. Quiroga S, Alvarez-Castells A, Pallisa E, Sebastia MC: Duodenal schwannoma causing gastrointestinal bleeding: helical CT findings. Abdom Imaging 1997, 22:154-155.

16. Rueda O, Escribano J, Vicente JM, Garcia F, Villeta R: Gastrointestinal autonomic nerve tumors (plexosarcomas). Is a radiological diagnosis possible? Eur Radiol 1998, 8:458-460.

17. Okada N, Hirooka Y, Itoh A, Hashimoto S, Niwa K, Ishikawa H, Itoh T, Kawashima H, Goto H: Retroperitoneal neurilemoma diagnosed by EUS-guided FNA. Gastrointest Endosc 2003, 57:790-792.

18. Stelow EB, Lai R, Bardales RH, Linzie BM, Mallery S, Stanley MW: Endoscopic ultrasound-guided fine-needle aspiration cytology of peripheral nervesheath tumors. Diagn Cytopathol 2004, 30:172-177.

19. Larghi A, Noffsinger A, Dye CE, Hart J, Waxman I: EUS-guided fine needle tissue acquisition by using high negative pressure suction for the evaluation of solid masses: a pilot study. Gastrointest Endosc 2005, 62:768-774

20. Larghi A, Verna EC, Ricci R, Seerden TC, Galasso D, Carnuccio A, Uchida N, Rindi G, Costamagna G: EUS-guided fine-needle tissue acquisition by using a 19-gauge needle in a selected patient population: a prospective study. Gastrointest Endosc 2011, 74:504-510.

21. Skopelitou AS, Mylonakis EP, Charchanti AV, Kappas AM: Cellular neurilemoma (schwannoma) of the descending colon mimicking carcinoma: report of a case. Dis Colon Rectum 1998, 41:1193-1196.

22. Miettinen M, Lasota J: Gastrointestinal stromal tumors-definition, clinical, histological, immunohistochemical, and molecular genetic features and differential diagnosis. Virchows Archiv 2001, 438:1-12.

23. Miettinen M, Shekitka KM, Sobin LH: Schwannomas in the colon and rectum: a clinicopathologic and immunohistochemical study of 20 cases. Am J Surg Pathol 2001, 25:846-855.

24. Maciejewski A, Lange D, Wloch J: Case report of schwannoma of the rectum-clinical and pathological contribution. Med Sci Monit 2000 76:779-782.

25. Pollock J, Morgan D, Denobile J, Williams J: Adjuvant radiotherapy for gastrointestinal stromal tumor of the rectum. Dig Dis Sci 2001, 46:268-272.

26. Wilhelm D, von Delius S, Weber L, Meining A, Schneider A, Friess H, Schmid RM, Frimberger E, Feussner H: Combined laparoscopic-endoscopic resections of colorectal polyps: 10-year experience and follow-up. Surg Endosc 2009, 23:688-693.

27. Teitelbaum EN, Nguyen SQ, Zhu H, Salky BA: Laparoscopic resection of a schwannoma of the ascending colon. Am Surg 2010, 76:E97-E99.

doi:10.1186/1477-7819-10-81

Cite this article as: Kim et al: Schwannoma of ascending colon treated by laparoscopic right hemicolectomy. World Journal of Surgical Oncology 2012 10:81.

\section{Submit your next manuscript to BioMed Central and take full advantage of:}

- Convenient online submission

- Thorough peer review

- No space constraints or color figure charges

- Immediate publication on acceptance

- Inclusion in PubMed, CAS, Scopus and Google Scholar

- Research which is freely available for redistribution

Submit your manuscript at www.biomedcentral.com/submit
C BioMed Central 